\begin{tabular}{l|l|l}
\hline \hline Vol. 28(1):37-43 & Ocean and Polar Research & March 2006 \\
\hline \hline
\end{tabular}

\title{
Article
}

\author{
극지미세조류의 유용성분 함량 및 항산화 활성

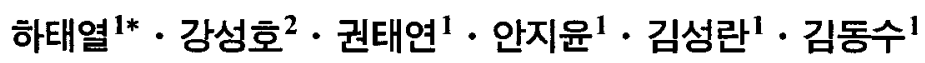 \\ 1한국식품연구원 식품기능연구본부 \\ (463-746) 경기도 성남시 분당구 백현동 산 46-1번지 \\ 2한국해양연구원 부설 극지연구소 \\ (425-600) 경기도 안산시 안산우체국사서함 29호
}

\section{Antioxidant Activity and Contents of Bioactive Components in Polar Microalgae}

\author{
Tae-Youl Ha ${ }^{1 *}$, Sung-Ho Kang ${ }^{2}$, Tae-Youn Kwon', Ji-Yun Ahn $^{1}$, \\ Sung Ran Kim ${ }^{1}$, and Dong-Soo Kim ${ }^{1}$ \\ ${ }^{1}$ Food Function Research Division \\ Korea Food Research Institute, Seongnam 463-420, Korea \\ ${ }^{2}$ Korea Polar Research Institute, KORDI \\ Ansan P.O. Box 29, Seoul 425-600, Korea
}

\begin{abstract}
In this study, bioactive components such as polyohenols, flavonoids and tocopherols were determined in cultured polar microalgae (Fragilariopsis pseudonana, Chaetoceros neogracile, Stellarima microtrias, Porosiara pseudodenticular). Antioxidant activity of methanol extracts of polar microalgae was also investigated. $\alpha$-Tocopherol contents in Fragilariopsis pseudonana were almost two times higher than those of Chaetoceros neogracile in. The antioxidant activity of methanol extracts of Fragilariopsis pseudonana methanol extracts determined by ABTS assay was higher than other algae. Total polyphenol contents of methanol extracts also showed a similar trend as antioxidant activity. The protective activity against oxidative damages induced by glutamate in PC 12 cells was shown in only Chaetoceros neogracile.
\end{abstract}

Key words : microalgae, tocopherol, ABTS, DPPH

\section{1. 서 론}

미세조류는 전 세계적으로 수천종이 수집되어 있고 일 부에서 화학적 조성이 밝혀지고 있으며 그 중 극히 일부 는 산업적 규모로 배양되고 있으며 이러한 미세조류의 자 원확보 및 이용에 대한 세계 각국의 연구는 매우 활발하 다. 그 대표적인 예로 클로렐라, 스피룰리나와 같은 미세 조류에 대해서는 상당히 많은 관심이 집중되고 있으며 우

*Corresponding author. E-mail : tyhap@kfri.re.kr
리나라를 비롯하여 일본, 중국에서는 이미 건강식품으로 활용되고 있다. 클로렐라는 고단백식품으로 필수 아미노 산함량이 높고 함유지방의 $67 \%$ 가 불포화지방산이며 각종 비타민, 무기질 함량이 높을 뿐 아니라 유산균 성장 촉진 물질로서 핵산관련물질중의 하나인 클로렐라 성장촉진인 자(chlorella growth factor, $\mathrm{CGF}$ 가 포함되어 있어 품질의 지표가 되고 있다(Kang et al. 2004). 클로렐라 열수추출 물은 hepatoma cell에서의 radical scavenging activity, antiproliferative activity, cell cycle arrest, macrophage의 cytokines 분비중강, rat과 hamster에서의 dyslipidemia를 
예방하고 항동맥경화 효능이 있는 것으로 보고되어 있으 며, peritoneal macrophage와 liver에서 산화적 스트레스를 줄이고 염증을 억제하는 항산화 활성을 갖는다고 보고된 바 있다(Cherng and Shin 2005). 사람을 대상으로 한 실 험에서도 클로렐라의 섭취는 고콜레스테롤혈증 환자의 혈 중 콜레스테롤을 감소시키는 효과가 있는 것으로 보고되 고 있다 (Okudo et al. 1975). 이와 같이 미세조류에는 다 양한 생리활성 물질이 함유되어 있고, 미세조류의 생리활 성은 종에 따라 차이가 있으며(Guzman et al. 2001), 동일 종이라도 배양조건에 따라 유용 성분의 함량 및 생리활성 에 차이가 있는 것으로 보고되고 있다(Miranda et al. 2001).

이러한 관점에서 미루어 볼 때, 극지 미세조류는 극한 환경에서 생육되는 만큼, 극지미세조류가 생성해내는 대 사산물들은 일반 미세조류와는 매우 다를 것으로 예상되 고 있으나 이에 대한 연구는 거의 전무한 상태이다. 그러 나 최근 극지생물의 생물공학적 이용을 위하여 선진 각국 에서 관심이 집중되면서 이러한 극지생물을 이용한 결빙 방지물질 등과 같은 유용물질의 개발 둥으로 미루어 볼 때 극지 미세조류에서도 다양한 유용성분과 생리활성이 기대되고 있다. 따라서 본 연구에서는 극지미세조류에 대 한 식품학적, 영양학적 기초 자료 확보의 일환으로 극지연 구소에서 배양된 극지미세조류 3종에 대하여 아미노산, $\mathrm{GABA}$ 및 항산화물질 둥 유용성분의 함량을 분석하고 산 화적 스트레스를 억제하는 항산화 활성 및 신경세포 보호 활성을 평가하였다.

\section{2. 재료 및 방법}

\section{재료}

본 실험에서는 극지연구소로부터 Fragilariopsis pseudonana (FP), Chaetoceras neogracile(CN), Stellarima microtrias (SM) 3종의 극지미세조류를 공급받아 사용하 였다.

\section{총 아미노산 조성 및 yaminobutric acid(GABA) 함량} 분석

총 아미노산 분석을 위하여 동결건조한 시료 $10 \mathrm{mg}$ 을 $1000 \mu l$ 증류수에 녹인 후 $30 \mu \mu$ 씩 분주하여 분석에 사용 하였다. 가수분해를 위해 취한 시료 각각을 완전히 건조시 키고, $110^{\circ} \mathrm{C}$ 에서 24 시간 $6 \mathrm{~N} \mathrm{HCl}$ 로 가수분해하였다. 가 수분해된 아미노산을 phenylisothiocyanate(PITC)로 유도 체화시키고, 시료를 완전히 말려 $200 \mu$ 의 용매 $1.4 \mathrm{mM}$ $\mathrm{NaHAc}, 0.1 \% \mathrm{TEA}, 6 \% \mathrm{CH}_{3} \mathrm{CN}$ )로 녹여 원심분리 후, 상 충액만을 $0.45 \mu \mathrm{m}$ filter로 여과하여 HPLC를 사용하여 Pico-Tag의 방법(Young-In Co. 1992)으로 분석하였다. 또
Table 1. Conditions of high performance liquid chromatography for analysis of tocopherols in polar micro-algae.

\begin{tabular}{ll}
\hline Detector & UV/vis absorbance, Fluorescence \\
Column & Nova-Pak C18 $(3.9 \times 150 \mathrm{~mm}, 4 \mu \mathrm{m}$, Waters $)$ \\
& $\mathrm{A} / \mathrm{B} / \mathrm{C} / \mathrm{D}=45: 40: 5: 10(\mathrm{v} / \mathrm{v}), 3 \mathrm{~min} \rightarrow \mathrm{A} / \mathrm{B} / \mathrm{C} / \mathrm{D}$ \\
& $=45: 45: 5: 5(\mathrm{v} / \mathrm{v}), 4 \mathrm{~min} \rightarrow \mathrm{A} / \mathrm{B} / \mathrm{C}=25: 70: 5(\mathrm{v} /$ \\
Solvents $^{*}$ & $\mathrm{v}), 14 \mathrm{~min} \rightarrow \mathrm{A} / \mathrm{B} / \mathrm{C}=25: 70: 5(\mathrm{v} / \mathrm{v}), 25 \mathrm{~min} \rightarrow$ \\
& $\mathrm{B} / \mathrm{C}=95: 5(\mathrm{v} / \mathrm{v}), 27 \mathrm{~min} \rightarrow \mathrm{B} / \mathrm{C}=95: 5(\mathrm{v} / \mathrm{v})$, \\
& $28 \mathrm{~min} \rightarrow$ initial \\
Wave length & Excitation $298 \mathrm{~nm}$, Emission $328 \mathrm{~nm}$ \\
Flow rate & $0.8 \mathrm{~m} / / \mathrm{min}$ \\
Injection vol. & $20 \mu l$ \\
\hline
\end{tabular}



한 $\mathrm{GABA}$ 함량 분석을 위하여 시료 $10 \mathrm{mg}$ 을 $1000 \mu l$ 증 류수에 녹인 후 $50 \mu \mu$ 씩 분주하여 건조시켰다. 이 건고물 은 phenylisothiocyanate(PITC)로 유도체화하여 다시 완전 히 말린 후 $200 \mu$ 의 용매( $1.4 \mathrm{mM} \mathrm{NaHAc}, 0.1 \% \mathrm{TEA}$, $6 \% \mathrm{CH}_{3} \mathrm{CN}$ )로 녹여 총 아미노산 조성과 같은 방법으로 처리하여 분석하였다.

\section{Tocopherol 분석}

시료중의 $\alpha-\beta, \gamma, \delta$-tocopherol의 함량은 Chen 둥 (2005)의 방법을 변형하여 분석하였다. 즉, 동결 건조한 시료 $50 \mathrm{mg}$ 에 $3 \mathrm{ml}$ 메탄올을 가하여 상은에서 3 분간 강 력한 vortex mixing한 뒤 $825 \times \mathrm{g}$ 로 5 분간 원심분리하였 고, 상층액은 $0.45 \mu \mathrm{m}$ filter(Millipore)로 여과하여 high performance liquid chromatography(HPLC)로 분석하였다. 모든 추출과 분석은 3 회 반복 실험하였고, HPLC 분석 조 건은 Table 1에 나타내었다.

\section{총 플라보노이드 및 총 폴리페놀 분석}

3 종의 극지미세조류는 $80 \%$ 메탄울로 3번 반복 추출하 고 $8000 \mathrm{rpm}$ 에서 30 분간 원심분리한 상둥액을 여과하여 rotary evaporator로 감압농축한 뒤 이를 메탄올 추출물로 사용하였다. 각 시료의 총 플라보노이드는 시료의 메탄올 추출물 $100 \mu$ 에 diethylene glycol $1 \mathrm{~m} /$ 을 첨가하여 균질 화한 후, $1 \mathrm{~N} \mathrm{NaOH} 100 \mu$ 를 첨가하여 $37^{\circ} \mathrm{C}$ 에서 1 시간 방치하고 UV Spectrophotometer(V-530, JASCO, JAPAN) 를 사용하여 $420 \mathrm{~nm}$ 에서 홉광도를 측정하여 분석하였고, 표준물질은 naringin으로 하여 환산하였다. 총 폴리페놀은 시료 $100 \mu$ 에 $2 \%$ sodium carbonate $2 \mathrm{~m} /$ 을 첨가하여 균 질하고 $2 \mathrm{~N}$ folin 용액을 $100 \mu l$ 첨가하여 상온에서 30 분 간 방치 후, $750 \mathrm{~nm}$ 에서 흡광도를 측정하여 분석하였고 표준물질은 (+)-catechin으로 하여 환산하였다(Gahler et al. 2003; Katsube et al. 2004). 
DPPH 라디칼 소거 활성 측정

시료의 메탄올 추출물 $20 \mu l$ 와 $4 \times 10^{4}$ M 1,1-diphenyl2-picrylhydrazy(DPPH: Sigma chemical Co.) 용액 $80 \mu \mathrm{l}$ 를 혼합하여 상온에서 15 분간 방치시킨 후, DPPH 용액의 free radical이 소거되어 감소되는 홉광도 값을 $525 \mathrm{~nm}$ 에 서 홉광도를 측정하였으며(Abe et al. 1998; Blois MS. 1958; Yen et al. 2002) 대조구로는 시료 대신 $100 \%$ 메탄 올을 가하였다. 시료 첨가구와 비첨가구의 흡광도차를 백 분율로 표시하여 DPPH radical scavenging activity(\%)로. 나타내었다.

\section{ABTS 라디칼 소거 활성 측정}

극지미세조류 메탄올 추출물의 ABTS 라디칼 소거활성 은 Amao 둥(Arano et al. 2001)의 방법에 따라 분석하였 다. 즉, 2,2'-Azino-bis-(3-ethylbenzothiazoline-6-sulfonic acid) (ABTS, Sigma Chemical Co.) $2.5 \mathrm{mM}$ 과 2,2'-azobis(2amidino-propane) dihydrochloride (AAPH)를 각각 $150 \mathrm{mM}$ $\mathrm{NaCl}$ 이 포함된 $100 \mathrm{mM}$ potassium phosphate buffer $(\mathrm{pH}$ 7.4) 용액에 녹여 $1: 1$ 로 혼합하고 $68^{\circ} \mathrm{C}$ 항온수조에서 일정 시간 방치하여 $\mathrm{ABTS} \cdot{ }^{+}$양이온을 형성시켜 $734 \mathrm{~nm}$ 에서 홉광도 값이 $0.650 \pm 0.02$ 가 되도록 조절하였다. 이 용액 $980 \mu$ 에 농도별로 희석한 메탄올 추출액 $20 \mu l$ 를 가하여 $37^{\circ} \mathrm{C}$ 에서 정확히 10 분간 반응시킨 후에 홉광도의 변화를 측정하여 소거활성을 구하였다. 또한, 추출액의 농도를 달 리하여 소거활성을 측정하여 $50 \%$ 의 소거활성을 나타내는 농도인 $\mathrm{IC}_{50}$ 값을 측정하였다.

\section{신경세포 보호활성}

신경세포 보호활성 실험에 사용한 세포주는 rat pheochromocytoma PC 12로써 한국세포주은행(KCLB)에서 분양받아 사용하였고 $10 \%$ inactivated horse serum (GIBCO, USA)과 5\% fetal bovine serum(GIBCO, USA) 이 첨가된 RPMI 1640 (GIBCO, USA, $25 \mathrm{unit} / \mathrm{m} /$ penicillin, 25 unit $/ \mathrm{m} l$ streptomycin) 배지를 이용하여 $37^{\circ} \mathrm{C}, 5 \% \mathrm{CO}_{2}$ incubator에서 배양하였다. 배양된 PC12 cell을 $2.5 \times 10^{4}$ cell/well 농도로 96 well plate에 접종한 후 24시간 동안 배양하였고 $20 \mathrm{mM}$ glutamate와 극지미세조류 메탄올 추 출물을 농도별로 처리하여 48 시간 배양하였다. 배양 후 MTT 시약을 $50 \mu \mathrm{g}$ 첨가하여 4시간 후 생성된 formazan 을 DMSO로 용해하여 ELISA microplate reader(Molecular devices, THERBO Emax, USA)로 $540 \mathrm{~nm}$ 에서 홉광도를 측정하였다. 극지미세조류 메탄올 추출물의 신경세포보 호활성은 glutamate와 시료를 첨가한 세포의 생존율이 glutamate를 첨가하지 않은 정상군 세포의 생존율에 대한 백분율(\%)로 나타내었다.

\section{3. 결 과}

\section{총 아미노산 조성 및 GABA 함량}

총 아미노산의 조성을 분석한 결과는 Table 2 와 같다. 총 아미노산 조성은 GLX, LEU, LYS, ALA 순으로 높게 나타나 이들 필수아미노산이 극지 미세조류의 주된 아미 노산인 것으로 나타났으며, HIS, TYR, MET은 비교적 낮 은 값을 나타내었다. 종별로 보면 Stellarima microtrias이 $12268 \mathrm{mg} / 100 \mathrm{~g}$ 으로 가장 높았고 다음은 Fragilariopsis pseudonana로서 $6759 \mathrm{mg} / 100 \mathrm{~g}$, Chaetoceros neogracile 는 $4051 \mathrm{mg} / 100 \mathrm{~g}$ 으로 가장 낮았으며 Fragilariopsis pseudonana의 $1 / 3$ 수준을 나타내어 시료간에 큰 차이를 보였다(Fig. 1). 또한 $\mathrm{GABA}(\gamma$-aminobutric acid)는 비단백 태 아미노산의 일종으로 glutamic acid decarboxylase의 촉매작용에 의해 glutamic acid로부터 생합성되며, 식물계 에 널리 분포된 생리활성 물질로서 콜레스테롤 강하효과, 혈압조절효능 등이 보고되어 최근 $\mathrm{GABA}$ 함량을 높이는 소재 개발연구들이 진행되고 있다. 극지미세조류의 GABA 함량을 분석해 본 결과 Stellarima microtrias가 경우 54 $\mathrm{mg} / 100 \mathrm{~g}$ 로 가장 높았으며 Fragilariopsis pseudonana보 다는 3.6배, Chaetoceros neogracile 보다는 약 6배 가량 높은 값을 나타내었다(Fig. 1).

Table 2. Composition of total amino acids in polar micro -algae. $(\mathrm{mg} / 100 \mathrm{~g})$

\begin{tabular}{lccc}
\hline & $\begin{array}{c}\text { Fragilariopsis } \\
\text { pseudonana }\end{array}$ & $\begin{array}{c}\text { Chaetoceros } \\
\text { neogracile }\end{array}$ & $\begin{array}{c}\text { Stellarima } \\
\text { microtrias }\end{array}$ \\
\hline ASX $^{*}$ & 310 & 117 & 762 \\
GLX $^{* *}$ & 879 & 416 & 1644 \\
SER & 405 & 241 & 687 \\
GLY & 444 & 246 & 764 \\
HIS & 152 & 73 & 275 \\
ARG & 510 & 294 & 735 \\
THR & 438 & 240 & 748 \\
ALA & 558 & 345 & 933 \\
PRO & 348 & 231 & 643 \\
TYR & 191 & 105 & 324 \\
VAL & 471 & 294 & 810 \\
MET & 193 & 139 & 361 \\
ILE & 388 & 267 & 662 \\
LEU & 586 & 402 & 1089 \\
PHE & 407 & 287 & 697 \\
LYS & 665 & 345 & 1081 \\
\hline
\end{tabular}

$\overline{\mathrm{ASX}^{*} \text {, asparagine and aspartic acid; } \mathrm{GLX}^{* *} \text {, glutamine and glutamic }}$ acid. 

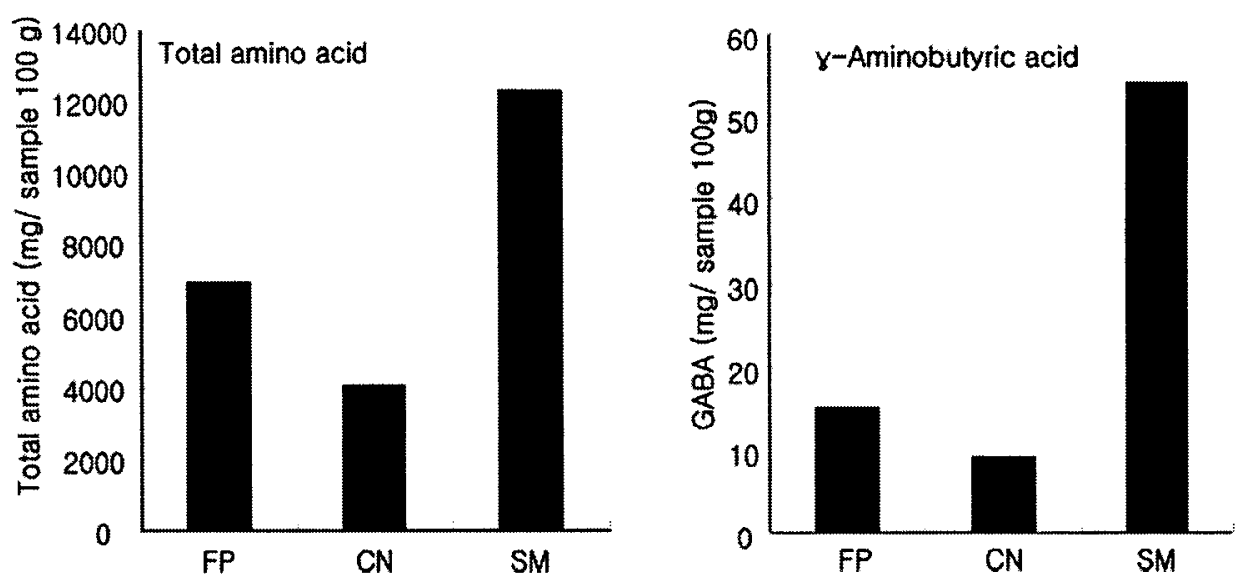

Fig. 1. Contents of total amino acid and GABA( $\mu$ Aminobutyric acid) in polar micro-algae (FP, Fragilariopsis pseudonana; CN, Chaetoceros neogracile; SM, Stellarima microtrias).

Table 3. Contents of tocopherols in polar micro-algae. $(\mu \mathrm{g} / 100 \mathrm{~g})$

\begin{tabular}{lccc}
\hline & \multicolumn{3}{c}{ Tocopherols } \\
\cline { 2 - 4 } & $\alpha$ & $\beta+\gamma$ & $\delta$ \\
\hline Fragilariopsis pseudonana & 1035.7 & 43.9 & 198.4 \\
Chaetoceros neogracile & 553.5 & 8.6 & 21.4 \\
Stellarima microtrias & ND & ND & ND \\
\hline
\end{tabular}

\section{Tocopherol 분석}

HPLC를 이용하여 tocopherol을 분석한 결과, $\beta, \gamma$ isomer를 제외한 peak 분리에 성공하였고, elution profile 에 대한 서열은 $\delta,(\beta+\gamma)$-, $\alpha$-tocopherol 순으로 나타났으 며 각각의 함량을 분석한 결과(Table 3), Fragilariopsis pseudonana의 경우 $\alpha$-, $(\beta+\gamma)-, \delta$-tocopherol의 함량이 각 각 $1035.7 \mu \mathrm{g} / 100 \mathrm{~g}, 43.9 \mu \mathrm{g} / 100 \mathrm{~g}, 198.4 \mu \mathrm{g} / 100 \mathrm{~g}$ 로 세 종류의 극지미세조류 중에서 가장 높게 나타났으며, 반면 Stellarima microtrias에서는 $\alpha-,(\beta+\gamma), \delta$-tocopherol이 검출되지 않아 다양한 극지미세조류의 종류에 따른 차이 를 나타내었다.

\section{총 플라보노이드 및 총 폴리페놀 함량}

극지미세조류의 메탄올 추출물을 이용하여 총 플라보노 이드 및 폴리페놀 함량을 측정한 결과는 Table 4와 같다. 각 시료들 중의 총 폴리페놀 함량은 $162-665 \mathrm{mg} / 100 \mathrm{~g}$ ext 범위를 나타내었으며 Fragilariopsis pseudonana에서 가장 높은 함량 나타낸 반면 Chaetoceros neogracile에서는 가장 낮은 함량을 나타내었다. 그러나 총 플라보노이드 함 량은 Stellarima microtrias 추출물이 $686 \mathrm{mg} / 100 \mathrm{~g}$ ext.로 가장 높은 함량을 나타낸 반면 Fragilariopsis pseudonana에 서는 $229.3 \mathrm{mg} / 100 \mathrm{~g}$ ext.이었으며 Chaetoceros neogracile
Table 4. Contents of total polyphenols and flavonoids in polar micro-algae. (mg/100 g ext.)

\begin{tabular}{lcc}
\hline & Polyphenols & Flavonoids \\
\hline Fragilariopsis pseudonana & 665.1 & 229.3 \\
Chaetoceros neogracile & 162.5 & 19.8 \\
Stellarima microtrias & 463.0 & 686.7 \\
\hline
\end{tabular}

은 가장 낮은 폴리페놀 및 총 플라보노이드 함량을 나타 내었다.

\section{라디칼 소거 활성 능력}

각 시료 메탄올 추출물의 DPPH radical scavenging activity를 분석한 결과, Fragilariopsis pseudonana, Chaetoceros neogracile, Stellarima microtrias, 모두 첨가농도 가 증가할수록 활성이 증가하였고 $1 \mathrm{mg}$ 의 메탄올 추출물 첨가 시 약 40-50\% 정도의 라디칼 소거능을 나타내었으 나 시료 간에 뚜렷한 차이는 나타나지 않았다(Fig. 2). 또 한 ABTS radical scavenging activity는 $\mathrm{AAPH}$ 와의 반응 에 의해 생성된 $\mathrm{ABTS}{ }^{+}{ }^{+}$free radical이 항산화 물질에 의 해 제거되는 원리를 이용하여 항산화능을 측정하는 방법 으로 메탄올1 추출물의 ABTS radical scavenging activity 를 측정한 결과(Fig. 3), Fragilariopsis pseudonana 추출 물이 가장 높은 활성을 보였으며 다음은 Chaetoceros neogracile, Stellarima microtrias 순이었고 모두 농도 의 존적 반응을 나타내었다. 또한 각 시료의 $\mathrm{IC}_{50}$ 값을 비교 한 결과, Fragilariopsis pseudonano는 $124.9 \mu \mathrm{g}$, Chaetoceros neogracile는 $288.5 \mu \mathrm{g}$ 그리고 Stellarima microtrias는 $345.7 \mu \mathrm{g}$ 으로 나타나 Fragilariopsis pseudonana에서 가 장 낮은 $\mathrm{IC}_{50}$ 을 나타내어 시험 시료 중 Fragilariopsis pseudonana가 가장 강한 항산화활성을 있는 것으로 나 타났다. 




Fig. 2. Antioxidant activities of $80 \%$ methanol extracts of polar micro-algae determined by DPPH method (FP, Fragilariopsis pseudonana; CN, Chaetoceros neogracile; SM, Stellarima microtrias).

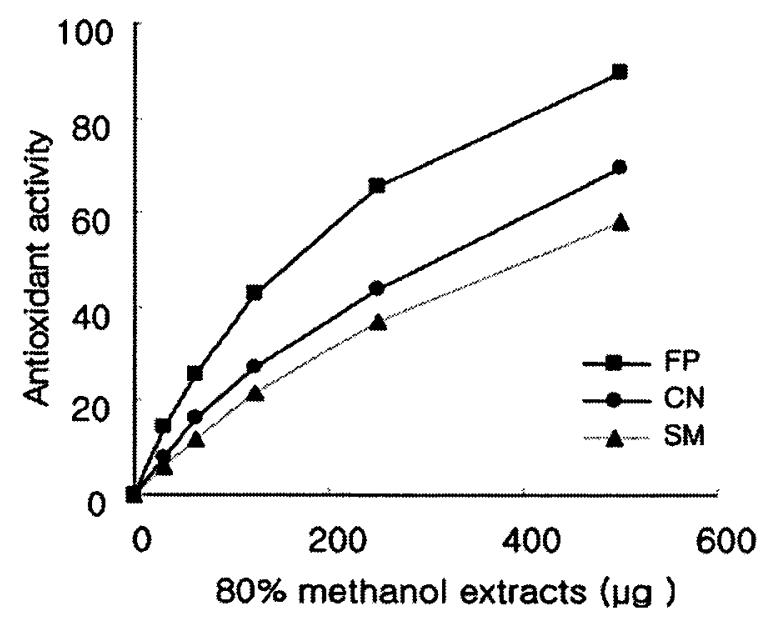

Fig. 3. Antioxidant activities of $80 \%$ methanol extracts of polar micro-algae determined by ABTS method (FP, Fragilariopsis pseudonana; CN, Chaetoceros neogracile; SM, Stellarima microtrias).

\section{신경세포보호 활성}

Glutamate는 중추신경계의 주요 신경흥분 전달물질로서 뇌신경세포에 과다하게 축적된 glutamate는 산화적 stress 를 유발하여 세포의 변성 및 사멸을 초래할 수 있다(Naito et al. 1995). $\mathrm{PCl} 2$ 세포를 이용하여 glutamate의 농도별 세포독성을 알아본 예비실험 결과, glutamate의 농도가 증 가할수록 세포의 독성이 증가하였으며 세포의 $50 \%$ 사멸 을 나타내는 $\mathrm{EC}_{50}$ value는 약 $20 \mathrm{mM}$ 의 농도로 나타났 다. 이 결과를 바탕으로 본 실험에서는 $20 \mathrm{mM}$ 의 glutamate 로 PC12 세포에 산화적 stress를 가한 뒤 극지미세조류 추 출물의 glutamate 독성에 대한 신경세포보호능을 검토하

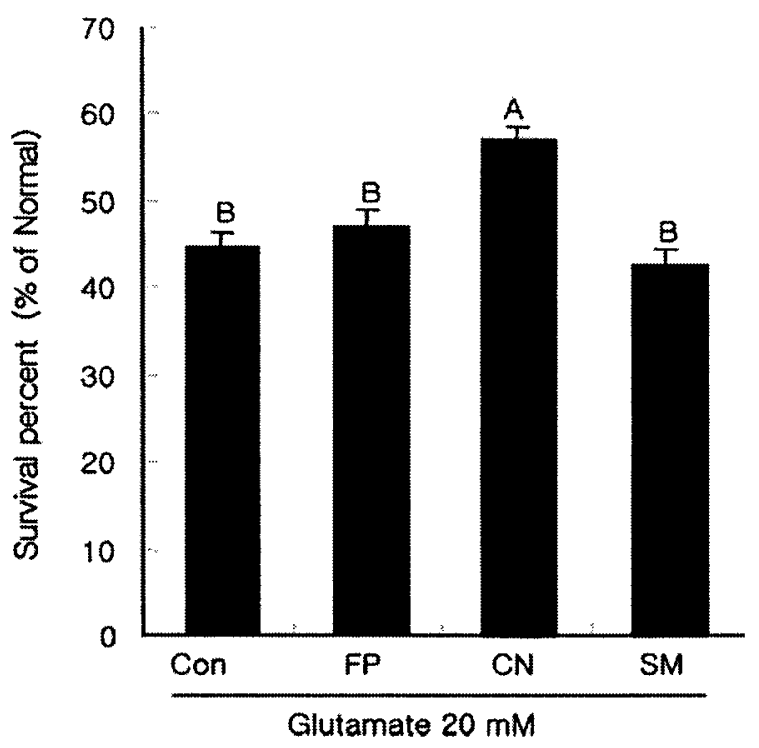

Fig. 4. Effects of $80 \%$ methanol extracts of polar microalgae on glutamate-induced cytotoxicity in PC12 cells (Con, Control; FP, Fragilariopsis pseudonana; CN, Chaetoceros neogracile; SM, Stellarima microtrias) Different letters are significantly different $(\mathbf{p}<0.005)$ by Dunncan's multiple range test).

였다(Fig. 4). 그 결과 Chaetoceros neogracile이 대조군에 비하여 세포생존율이 유의하게 증가하여 L-glutamate에 의한 세포사멸을 억제함을 알 수 있었으나 Fragilariopsis pseudonana와 Stellarima microtrias의 추출물에서는 세포 보호능이 나타나지 않았다.

\section{4. 고 찰}

본 연구에서 극지미세조류 3 종에 대하여 유용성분을 분 석한 결과, 총아미노산 및 $\mathrm{GABA}$ 함량은 Stellarima microtrias에서 가장 높았고 tocopherol이나 총 폴리페놀 함량은 Fragilariopsis pseudonana 가장 높은 함량을 보 여, 유용성분의 함량은 종에 따라 상당히 차이가 있음을 알 수 있었다. 이러한 결과는 극지미세조류에 대한 기존 연구결과가 없어 직접적인 비교는 어려우나, 일반 미세조 류의 경우에도 종에 따라 항염증활성 및 항산화 활성 둥 에 차이를 나타내며(Guzman et al. 2001), 또한 동일 종에 있어서도 배양온도에 따라 총 폴리페놀 함량이 다르다고 보고 한 Miranda 등(Miranda et al. 2001)의 연구결과들과 유사한 경향이다. 또한 각 시료 메탄올 추출물에 대한 항 산화 활성을 분석한 결과 Fragilariopsis pseudonana가 가장 높은 항산화 활성을 나타내었다. 이러한 결과는 Fragilariopsis pseudonana가 다른 종에 비하여 tocopherol 
함량이 가장 높았고 추출물의 총 폴리페놀 함량도 가장 높았던 점을 고려해 볼 때 radical scavenging activity는 tocopherol과 폴리페놀 화합물에 기인한 것으로 사료되었 다. 또한 이러한 항산화 활성이 ABTS assay에서는 높게 나타났으나 DPPH assay에서는 전반적으로 낮은 활성을 보였고 시료 간에 큰 차이가 나타나지 않았다. ABTS assay와 DPPH assay간의 반응의 차이는 두 방법 모두가 인위적으로 형성된 free radical을 제거한다는 공통기작을 가지나 각 항산화물질에 대한 반응정도에는 차이가 있는 것으로 추정되었다. 이러한 결과는 폴리페놀물질의 하나 인 (+)-1-hydroxypinoresinol-1- $\beta$-D-glycoside와 homoplantaginin은 ABTS ${ }^{+}$free radical에 대한 제거능은 있지 만 DPPH - free radical의 제거능은 나타나지 않는다는 Wang등의 보고(Wang et al. 1998)와도 유사한 경향이라 볼 수 있으며 향후 극지 미세조류에서도 (+)-1-hydroxypinoresinol-1- $\beta$-D-glycoside와 homoplantaginin의 분석 등 이 요구된다. $\mathrm{Wu}$ 등(2005)의 연구에 따르면 클로렐라와 스피룰리나의 수용성 추출물을 이용하여 ABTS assay 결 과 $\mathrm{IC}_{50}$ 값이 약 $200 \mu \mathrm{g}$ 였고, hepatoma cello apoptosis를 유도하고 cell cycle을 arrest하는 효과가 있는 것으로 보고 하고 있다. 본 연구에 사용된 Fragilariopsis pseudonana 의 메탄올 추출물은 $\mathrm{ABTS}$ assay에서 $147.9 \mu \mathrm{g}$ 에서 $\mathrm{IC}_{50}$ 값을 나타내어보다 클로렐라와 스피룰리나 물 추출물보다 는 항산화활성이 높은 것으로 확인되었다. 한편, glutamate로 유도된 신경세포손상에 대하여 극지미세조류 의 보호활성을 검토한 결과, Chaetoceros neogracile 에서 만 유의한 보호활성이 나타났다. 그러나 Chaetoceros neogracile에서는 Fragilariopsis pseudonana에 비하여 tocopherol 및 총폴리페놀 함량이 낮았던 점을 고려해볼 때 Chaetoceros neogracile의 신경세포 보호활성은 항산 화 활성과는 다른 작용에 의하여 나타나는 것으로 사로되 며, 향후 이에 대한 자세한 연구가 요구된다.

\section{요 약}

본 연구에서는 Fragilariopsis pseudonana, Chaetoceros neogracile, Stellarima microtrias 3종 극지미세조류의 아 미노산, tocopherol 함랑을 비교하고, 메탄올 추출물로부 터 총폴리페놀 및 총 플라보노이드 함량을 분석함과 동 시에 항산화 활성 및 신경세포 보호능을 검토하였다. Fragilariopsis pseudonana의 $\alpha-(\beta+\gamma), \delta$-tocopherol 함 량이 가장 높은 깃으로 나타났고, 특히 Fragilariopsis pseudonana의 $\alpha$-tocopherol 함량은 Chaetoceros neogracile 보다 약 2배정도 높은 $1035 \mu \mathrm{g} / 100 \mathrm{~g}$ 인 것으로 확인되었 으나, Stellarima microtria 에서는 모두 검출되지 않았다. 또한 Fragilariopsis pseudonana의 추출물은 ABTS assay
에 의한 항산화 활성이 가장 높았으며 총폴리페놀 함량도 가장 높았다. 한편, 신경세포 보호활성은 Chaetoceros neogracile 추출물에서만 확인되었다.

\section{사 사}

본 연구는 2004년도 해양수산연구개발사업의 "극지생 물활웅연구" 과제의 지원에 의해 수행된 연구의 일부로 이에 감사드리며, 아미노산 분석을 도와주신 기초과학지 원연구소 아미노산 분석팀에 감사드립니다.

\section{참고문헌}

Abe, N., T. Murata, and A. Hirota. 1998. Novel 1,1diphenyl-2-picrylhydrazyl-radical scavengers, bisorbicillin and demethyltrichodimerol, from a fungus. Biosci., Biotechnol., Biochem., 62, 661-662.

Arnao, M.B., A. Cano, and M. Acosta. 2001. The hydrophilic and lipophilic contribution to total antioxidant activity. Food Chem., 73, 239-244.

Blois, M.S. 1958. Antioxidant determination by the use of a stable free radical. Nature, 181, 1199-1200.

Cano, A., J. Hernandez-Ruiz, F. Garcia-Canovas, M. Acosta, and M.B. Arnao. 1998. An end-point method for estimation of the total antioxidant activity in plant material. Phytochem. Anal., 9, 196-202.

Chen, M.H. and C.J. Bergman. 2005. A rapid procedure for analysing rice bran tocopherol, tocotrienol and $\gamma$-oryzanol contents. J. Food Compos. Anal., 18(4), 319-331.

Cherng, J.Y. and M.F. Shin. 2005. Preventing dyslipidemia by Chlorella pyrenoidosa in rats and hamster after chronic high fat diet treatment, Life Sci., 76, 3001-3013.

Emerit, J., M. Edeas, and F. Bricaire. 2004. Neurodegenerative diseases and oxidative stress. Biomed. Pharmacother, 58, 39-46.

Gahler, S., K. Otto, and V. Bohm. 2003. Alterations of vitamin $\mathrm{C}$, total phenolics, and antioxidant capacity as affected by processing tomatoes to different products. $J$. Agric. Food Chem., 51, 7962-7968.

Guzman, S., A. Gato, and J.M. Calleja. 2001. Antiinflammatory, analgesic and free radical scavenging activities of the marine microalgae Chlorella stigmatophora and Phaeodactylum tricornutum. Phytother. Res., 15, 224-230.

Kang, M.S., S.J. Sim, and H.J. Chae. 2004. Chlorella as a functional biomaterial. Kor. J. Biotechnol. Bioeng., 19(1), 1-11.

Katsube, T., H. Abata, Y. Ohta, Y. Yamasaki, E. Anuurad, K. Shiwaku, and Y. Yamane. 2004. Screening for antioxidant 
activity in edible plant products: comparison of lowdensity lipoprotein oxidation assay, DPPH radical scavenging assay, and Folin-Ciocalteu assay. J. Agric. Food Chem., 51, 7962-7968.

Miranda, M.S., S. Sato, and J. Mancini-Filho. 2001. Antioxidant activity of the microalga Chlorella vulgaris cultered on special condition. Boll. Chim. Farm. 140, 165-168.

Naito, M., H. Umegaki, and A. lguchi. 1995. Protective effects of probucol against glutamate-induced cytotoxicity in neuronal cell line PC12. Neurosci. Lett., 186, 211-213.

Okudo, M., T. Hasegawa, M. Sonoda, T. Okabe, and M. Tanaka. 1975. The effects of Chlorella on the level of cholesterol in serum. Jpn. J. Nutr, 33, 3-8.

Wang, M.F., Y. Shao, J.G Li, N.Q. Zhu, M. Rangarajan, E.J. Lavoie, and C.T. Ho. 1998. Antioxidative phenolic compounds from sage (Salvia officinalis). J. Agric. Food Chem., 46, 4869-4873.

Wu, L.C., J.A. Ho, M.C. Shieh, and I.W. Lu. 2005. Antioxidant and antiproliferative activities of spirulina and chlorella water extracts. J. Agric. Food Chem., 53, 4207-4212.

Yen, G.C., P.D. Duh, and H.L. Tsai. 2002. Antioxidant and pro-oxidant properties of ascorbic acid and gallic acid. Food Chem., 79, 307-313.

Young-In Scientific Co. 1992. Application of amino acid analysis system. Young-In Scientific Co. Ltd., Seoul, Korea.

Received Dec. 5, 2005

Accepted Mar. 8, 2006 